\title{
THE ECONOMIC AND POLITICAL PROBLEMS OF INTEGRATION
}

\author{
Albert Coppé*
}

I

\section{THE Task INvolved}

The task of integrating the economies of the six member countries of the Community, as set out in the Treaties establishing the European Communities, involves action over the whole field of economic activity. Since the aim is not merely to provide a free-trading area, but, in fact, to weld six national markets into a single Community market and a single Community production area, this integration involves a fundamental recasting of the economic structure over a period of time.

The system of integration chosen by the Six, with its three Communities, is not an ideal system. The European Coal and Steel Community (E.C.S.C.) was the pilot plant of European unity, and the defects of partial integration-integration of a sector of the economy only-were accepted for this reason. The European Atomic Energy Community (Euratom) arose, to some extent, because of the great need for a spectacular achievement on the road to unity at a moment when atomic power seemed to be one of the most important phenomena in the world. Then came a shift in emphasis-and how right it has proved-towards the European Economic Community (E.E.C.)-the Common Market. The development of the integration of the Six was thus a pragmatic evolution, with all the imperfections and inconsistencies, as well as some very great advantages of flexibility, that the system provides.

A pattern does emerge, however, from the different structures of the three Communities. It is possible to see this pattern both in the tasks that the Communities must accomplish and in the instruments- the institutional featurescreated to achieve them.

The tasks themselves can be summarized as follows:

\section{r. The abolition of trade barriers within the Community area}

This has involved removal of customs duties and all similar levies making the sale of goods from the rest of the Community more difficult than the sale of goods produced within a national market. It has also involved removal of quotas-i.e., all quantitative restrictions on imports and exports. This problem has become very

- Licenciate in Political and Social Sciences 1933, Doctor of Economic Sciences 1940, University of Louvain (Belgium). Vice President, High Authority of the European Coal and Steel Community; Chairman, Board of Management of the Statistics Office of the European Communities; Member, High Council of Statistics; Extraordinary Professor, School of Economic and Social Sciences, University of Louvain (Belgium); Minister for Public Works, 1950; Minister for Economic Affairs and Middle Classes, I950-5I; Minister for Reconstruction, I952. 
much less acute following the restoration of the French economy to health and the much more rapid progress of the industrialized western countries towards the removal of the quantitative restrictions. Finally, it has involved removal of currency restrictions-i.e., all barriers presented by difficulties in acquiring the currency of one or another of the member countries. This question has now been largely solved by the rapid move towards convertibility.

\section{Free circulation of factors of production}

The free circulation of goods has its counterpart in the free circulation of the factors of production-labor and capital-and in the free movement of services. It would be inconceivable to allow the free movement of goods to those areas of the Community that are underdeveloped and overpopulated if its counterpart did not exist in the form of the free movement of labor, and if these areas were not given the opportunity to import the capital that would enable them to close the gap. It looked at one time as if the free circulation of labor would present difficulties, but since the provisions of the E.E.C. Treaty allow workers to move from one country to another only to take up a specific job, the bulk of trade-union fears were assuaged.

The free movement of capital enables the spreading of the Community's investment resources. The free movement of services extends the principle of competition and the exploitation of a large market to all the auxiliary activities involved in the trade in goods-banking, insurance, the wholesale and retail trades, and so on.

\section{A common external tariff}

The E.E.C. Treaty stipulates the establishment of a common external tariff by the end of a transition period of ten to twelve years-a process that is now being speeded up, as is the abolition of trade barriers. The common external tariff is the factor that makes the Community of the Six a customs union and not a free trade area. By treating the Community as a single tariff area with a common tariff, the Treaty obviates all the innumerable problems-and, above all, bureaucratic complicationsthat would be presented by control of the origin of goods. The aim of the Community is to do away with customs formalities within its frontiers, not to redouble them.

The E.C.S.C. Treaty did not involve a common external tariff. The harmonization of the existing national tariffs was, however, effected at the low rate of the Benelux tariff plus two points, with an additional allowance for geographical protection.

\section{Common rules of competition}

A common market would not last long if the conditions of competition, in so far as they are determined by governmental and private measures, showed wide differences in the component parts of the area. The national and regional authorities would vie with each other in creating unfair advantages for their own industries, and the resultant distortions in competitive power would mean that the industries that 
would do best would not necessarily be the most efficient. Many efficient, and in: normal conditions, viable, industries would be driven to bankruptcy, and many inefficient industries would be preserved.

Integration must, therefore, inevitably include common rules of competition. In the Community, these cover, in general, the following fields:

a. Nondiscrimination-the application of comparable terms-among others, prices. and transport rates-to all consumers in the Community who are in comparable conditions.

b. A ban on subsidies and other state aids that favor industries in one part of the Common Market against those in others.

c. A ban on agreements in restraint of trade-i.e., agreements to restrict production, regulate prices, allocate markets or production, or restrict technical progress. In the E.C.S.C., this ban is backed by the requirement that all proposed agreements between firms must receive the prior authorization of the High Authority to becomevalid; authorization may be refused if the High Authority considers that the agreement is not in conformity with the Treaty's stipulations. The task of the Common Market is much broader, covering the whole field of economic activity.

d. There must be no abuse of a dominant power in the market by any firm or group of firms. Here, again, the High Authority has greater facilities, since mergers: between firms require prior authorization by the High Authority. In the general Common Market, moreover, the executive must seek out abuses before interdiction. While the bans on restrictive practices apply only when trade between Community countries is involved, the antitrust laws of the E.C.S.C. Treaty are not subject to, this limitation.

\section{Common policies}

The fundamental principle of all three Community Treaties is their insistence on action going far beyond the setting up of a customs union. In fact, it is quite: clear that it would be impossible to remove trade barriers if the six Governments. were to pursue their economic, financial, agricultural, transport, and foreign-trade policies on national lines, while industry and commerce were busy exploiting a vast new market. Deflation in one country while another inflated would mean that the former's goods would flood the latter's market. Differing forms of protection for agriculture would mean the maintenance of disparate price levels and would create such havoc in the markets that the establishment of a single market would becomeimpossible. Divergent action by national Governments in their foreign trade agreements would make nonsense of the common external tariff. Many more examples: could be given.

II

The Instruments of INTEgration

To achieve the task set out above, the European Communities provide an entirely new type of structure. They do not provide a federal system in which an executive 
has clear sovereign powers. Even in the E.C.S.C., where sovereign powers over a limited field have been transferred to the High Authority by the Governments, the panoply of sovereignty over the broad lines of economic policy as a whole remains in the hands of the Governments. In the E.E.C., the power of decision is retained by the Governments through the Council of Ministers. The Community might, therefore, appear at first sight to be very largely a form of confederate system, in which the ultimate powers are wielded by a body composed of representatives of the member Governments.

In fact, however, the institutional structure of the Communities, even in the form adopted for the E.E.C., has certain features going well beyond a confederate system and distinguishing it sharply from the organizations based on simple intergovernmental cooperation. These distinguishing features include the existence of strong independent executives, making their decisions by majority vote, and with clearly defined and fundamentally important powers.

\section{x. The European Coal and Steel Community}

The High Authority of the E.C.S.C. is able to make major decisions in the field of prices, investments, and the rules of competition without consulting the Council of Ministers. Even in the fields of transport and social policy, the High Authority has been able to make substantial progress, simply because it is a Community body with a kind of vested interest in ensuring that a Community solution is achieved to Community-wide problems.

\section{The European Economic Community ${ }^{1}$}

In the Common Market, the Commission proposes and the Council of Ministers disposes. But, after the initial four-year stage of the transition period, decisions in the Council of Ministers will be made mainly by a weighted majority vote. There is thus no question of a veto being exercised by one of the member countries.

In addition, the power of proposal by the E.E.C. Commission is an extremely efficient and potent instrument. It enables the Commission to gauge the climate of Community opinion and to push forward with measures that might never come to fruition if they had to have been formulated, proposed, and pushed through by national Governments or their representatives. The speeding-up of the Common Market timetable is a perfect example of the functioning of this process. It was the Commission that all along acted as the driving force. Not only did it produce the actual proposals that were discussed by the Council of Ministers, but it also worked hard on the proposals during the difficult discussions in the Council and was instrumental in producing the final compromises that were incorporated in the final draft.

Thus, the Communities' executives act as a motor or dynamo, in a way that has been conspicuously absent in the ministerial bodies of some organizations for simple

\footnotetext{
I The powers of the Euratom Commission are not dealt with here, since they occupy a position somewhere about halfway between those of the High Authority of the E.C.S.C. and those of the E.E.C. Commission.
} 
intergovernmental cooperation, and effectively fulfill their role of dealing with problems in the European Community interest, which is rarely the sum of the (conflicting) national interests. It is this realization of the common interest, and the spectacular benefits that its application is already bringing, that makes the proposals of the executives acceptable to the national Governments.

\section{The European Parliament}

The European Parliament is not a legislature, nor does it have any say in the appointment of the Governments of the European Community; but the r42-member Parliament can remove any of the three Communities' executives on a motion of censure voted by a two-thirds majority. Moreover, the European Parliament must be consulted before certain specific decisions are made, and it has a right to scrutinize the Communities' budgets. Through its thirteen standing committees, the Parliament also keeps a close watch on the work of the three executives and calls on their members to testify before these committees. Plans for direct election of members by universal suffrage have been drawn up by the Parliament itself, and this may well be a steppingstone to the further extension of the Parliament's powers.

\section{The Court of Justice}

Another common institution is a supreme court of seven judges having the sole power to decide whether the acts of the Communities' executives and the Council of Ministers should be upheld or quashed. The innovation as far as the Court is concerned is in the fact that its judgments have the force of law throughout the European Community and are directly binding on individuals, firms, national governments, and the Communities' executives.

Thus, the structure of the Communities presents something half-way between a true federal structure and the kind of intergovernmental cooperation we have seen in the past. It distinguishes itself from the latter systems by its dynamism and its. effectiveness. It can and should logically result one day in a full federation; but in the meanwhile, it has shown itself fully capable of standing on its own two feet.

\section{III}

\section{The Problems of Integration}

\section{A. The General Difficulties-Real and Imagined}

It was always clear that a gigantic task such as the integration of the economies of six countries would present a complex series of problems. In the first place, since the structure of the Communities was something entirely new, the task of fitting it into the existing national and industrial framework was bound to give rise to differing viewpoints among business men and politicians on the political approach in general and the methods of action. Those whose wishes were not met naturally felt aggrieved.

Secondly, a vast undertaking such as the economic union of the six countries 
was also bound to run up against vested interests over a wide area. There are always persuasive reasons for retaining the status quo in almost any field, particularly if it involves a good deal of protection. In business, it allows a relative degree of peace and quiet; and even if the economy lacks dynamism, industrialists and businessmen may find the additional security a more than adequate compensation. Some of the trade unions, too, felt at the start of the integration process that it might be the workers who would suffer from the expansion of competition in a six-country market of 160 million consumers.

Many of these anxieties were, in fact, dispelled when the Common Market actually came into being. This was true with the common market for coal and steel in 1953 , as it was true for the general Common Market in 1958 . Once industrialists and workers are caught up in the new spirit of dynamism and rapid advance of the Common Market and come to recognize the very great improvements it brings in sales, production, and living standards, they experience a sudden change of opinion and, it seems, a sudden change in outlook. Today, the results of the Common Market are being anticipated by the Community's industries, which are all basing their future production and sales plans on the existence of a market of continental size. The trade unions, on their side, are the most fervent supporters of European integration and of continued moves towards full unity.

Some industries, however, were clearly bound to experience genuine difficulties. The classic example is the Belgian coal industry. On the one hand, the common market for coal and steel has prevented the protraction of this industry's agonies by placing bounds on the national protection it can be granted; on the other, it has enabled reorganization to go forward with far less disagreeable social consequences than would have been possible if the E.C.S.C. were not providing the aid for reemployment, retraining, and resettlement of miners, known as "readaptation." In the general Common Market, moreover, there will undoubtedly be other cases where industries that were previously highly protected will have considerable difficulties in adapting themselves to new conditicns.

Here, however, a conscious policy of economic expansion can greatly ease the change. It is in times of recession that firms go to the wall. During expansionary periods, adaptation to the new conditions of increased competition in the Common Market occurs through more rapid expansion of the more efficient firms, rather than through an increase in the number of firms compelled to close down. At the same time, experience in the E.C.S.C. has shown that booms can mask a good deal of uneconomic activity. Thus, when the rate of economic expansion slackened at the end of $195^{8}$, the structural difficulties of parts of the Community's coal industry were suddenly revealed with full clarity.

The E.E.C. Commission regards a rapid rate of expansion as the fundamental pillar of the Community's economic policy, and has urged that an expansion rate of between four and five per cent per annum in the gross national product be achieved over the coming years. 


\section{B. Problems of Partial Integration in the European Coal and Steel Community}

Before dealing with the major practical problems, it is worth looking back on the problems of partial integration faced by the E.C.S.C. before the Common Market and Euratom came into being. The first and most obvious of these was the absence of the formulation of general economic policy and trade cycle policies from the field of power of the High Authority. Since this remained the responsibility of the six national Governments, cases could-and, in fact, did-arise in which the Community's price policy could be regarded as contrary to the general economic policy being followed at that time by individual member Governments. Freedom of coal and steel prices enables firms to charge prices during a boom that will not only finance a rapid rate of investment, but also permit these firms to mass reserves sufficient to finance price cuts during a recession. The Governments' interest during a boom, however, is to avoid inflationary pressures, and some of the Community Governments exerted considerable pressure on the prices of E.C.S.C. productspressure that was incompatible with the E.C.S.C. Treaty. When this particular problem arises, as it must from time to time, it should be remedied by recourse to article twenty-six of the Treaty, which provides for coordination of the High Authority policy with the general economic policies of the six Governments.

Secondly, the failure of the Treaty to grant the High Authority any powers over external trade meant that, before and during the coal crisis, the Governments were able to follow contradictory import policies. Some Governments feared the dislocation of their coal markets by the arrival of excessive quantities of coal from other Community countries, and the free circulation of coal in the Common Market was thus endangered. In the E.E.C. Treaty, this defect regarding external trade is remedied, and the Commission has important powers over the coordination of external trade policies.

Other problems of partial integration were apparent in the field of labor policy and transport. The labor policy of the High Authority, by granting especially favorable conditions to coal and steel workers, particularly in cases of unemployment and in housing questions, created difficulties, since the other sectors of industry were less favored. There were also problems of harmonizing transport rates and conditions, but these problems may well be repeated on the broader plane of the general Common Market.

The E.C.S.C. has also faced some extremely difficult problems in the field of competition. Articles sixty-five and sixty-six of the E.C.S.C. Treaty are quite unequivocal; banning agreements in restraint of trade and mergers that result in an excessive restriction of competition. These articles make agreements between firms and mergers of firms subject to authorization by the High Authority. They have been instrumental in enabling the High Authority to ensure that the trade barriers eliminated in the transition period were not replaced by private restrictions.

The strict nature of these two articles has applied much more exacting standards to the coal and steel industries than those applicable to other industries. Evidently 
the coal industry found this disparity even more burdensome when the coal crisis started. The sales organization for Ruhr coal provides a classic example. Believing that unbridled competition between the coal firms of the Ruhr was impracticable, the High Authority in 1956 ordered the dissolution of the monolithic sales cartel known as GEORG and authorized a system comprising three sales agencies that were to compete with each other. In fact, however, actual competition did not result. This system, which would have expired in March 1959, was extended for a year, while a new solution compatible with the Treaty was sought. The High Authority then refused a request of the Ruhr coal agencies for authorization of a single sales agency. The High Authority believes that should the Governments consider that competition is not capable of ensuring the efficient operation of the coal market in present conditions, the E.C.S.C. Treaty should be modified. This can only be done in accordance with the rules laid down for Treaty modifications, and, until that happens, the High Authority must apply the Treaty's rules of competition. In any event, there should be no doubt that, if living standards are to be raised, the maintenance of competition on the market is of fundamental importance, whatever the private interests involved, and the rules adopted to ensure this must be adequate and effective.

Although the E.C.S.C. has presented particular problems, its experience has been invaluable not only as a pilot operation which proved that integration could work successfully, but also as a model for the supranational pattern of organization that precludes domination by any of the Member States and guarantees the rights of the smaller countries.

\section{Agriculture}

It is impossible here to do any more than indicate the nature of the extensive problems faced by integration in such key fields of policy as agriculture. Agriculture presents a special problem in all highly developed industrial societies. In all of them, these problems have led to more or less extensive government intervention. This ranges from complete central organization of the internal market for particular products to relatively free systems. In all cases, however, agriculture is protected from foreign competition by a great variety of methods designed to raise the incomes of farmers, which tend to be lower than those of other groups.

In a common market, there can be no question of excluding agriculture. This would not only distort the whole integration system, but it would also discriminate against those countries in whose economies agricultural exports play a vital part. On the other hand, it would be unthinkable that the present basis of the Common Market's agriculture, which is the family holding, should disappear. The problem is, therefore, not whether there should be agricultural protection, but what degree of agricultural protection there should be and what methods should be used to achieve it. At the same time, ways must be found to ensure structural improvements and greater productivity, and protection should not be so great as to suppress any incentive in this direction. 
D. Transport

The E.C.S.C. Treaty abolished transport discriminations for coal, steel, iron ore, and scrap. It also directed the High Authority to try to find, in cooperation with the national governments, ways of harmonizing transport conditions for E.C.S.C. products. The E.E.C. Treaty requires the formation of a common transport policy, the basic principles of which the E.E.C. Commission expects to finish working out in the course of this year.

The major problem in this field, which has already come to the fore, is similar to that which has proved such a hard nut to crack in the E.C.S.C.- that of ensuring nondiscrimination in transport rates and conditions. While some of the Governments are strongly in favor of price publicity as the only really effective means of preventing discrimination, others are equally strongly opposed. Perhaps in the not too distant future, publicity for transport rates will be as widely accepted in the Community as it already is in the United States. There, the regulatory role of the Interstate Commerce Commission is accepted in the interests of fair competition, and no one would dream of calling it dirigiste.

\section{E. Competition}

The problems of competition will play an essential part in determining the form that the Common Market will eventually take. Such measures as the ban on state subsidies and other aids likely to distort competition by favoring certain firms will be difficult but should present no fundamental problems of principle. The real problems will rather arise when the E.E.C. Commission has defined its antitrust legislation and begins to enforce it.

So far, the E.E.C. Commission has been working to make it legally possible to apply in uniform fashion the rules of competition laid down in the E.E.C. Treaty. Belgium, Italy, and Luxembourg had no antitrust legislation at all and have had to adopt new measures that will enable a common policy on competition to be put into practice. The E.E.C. Commission has already presented to the Council of Ministers draft regulations on the control of cartels, which would greatly strengthen its hand in achieving effective control. At all events, the Commission is determined that abusive control of the market in the main industrial sectors shall not pass into the hands of cartels or a small number of enterprises, since this would be contrary to the aims of the Treaty.

\section{F. The Underdeveloped Regions of the Community}

One of the problems that has always beset customs unions has been the danger that investment from the whole area would tend to become increasingly concentrated in the well-developed areas, thus making the richer areas richer and the poor areas poorer-or relatively poorer, at any rate. The classic examples of development of this kind are the southern United States and southern Italy after the union of the peninsula. This tendency is attributable to the attraction that a high degree of 
economic development exerts on new industrial investment. Clearly, firms and individuals with capital to invest are likely to move towards regions that will have an adequate economic intrastructure, roads and railways on which to bring in their raw material and get out their finished products, schools and technical colleges to train a skilled and productive labor force, hospitals to treat their workers when they are ill, power stations to provide energy, and so on.

This problem has been faced in the E.E.C. by the establishment of the European Investment Bank, with a capital of $\$ 1,000,000,000$, of which $\$ 250,000,000$ has been paid up. This feature of the E.E.C. Treaty was particularly insisted upon by Italy, as the country of the Community with the largest underdeveloped region. It is a fact that investment in the rapidly developing industrial regions of northern Italy is still far outstripping investment in the underdeveloped South, despite the efforts of the Cassa del Mezzogiorno ${ }^{2}$ and the initial operations of the European Investment Bank. Ways may well have to be found to step up the operations of the Investment Bank in this field.

\section{G. The Associated Countries}

One of the most adventurous and spectacular features of the Community has been the association in a free and equal partnership with the Community of the countries and territories that had or have particular links with one of the Community's member countries. This forged a direct link between the Community and African territories with a population of about 53,000,000. It was particularly favorable to the associated countries in that it gives them free entry for their products into the Common Márket, while they themselves were allowed to retain customs duties required to protect their young industries. In addition, an Overseas Development Fund of \$581,250,000 was set up for an initial period of five years, to encourage social and economic development in the associated countries. The problem so far has been to find a rapid enough procedure to ensure speedy approval of all worthwhile projects. This problem is now on the way to being solved, however, and it is expected that projects will be approved more rapidly in the coming months. By the end of 1960 , the Commission had already approved the financing of 126 projects involving a total contribution of $\$ 121,000,000$. Among social projects, schools and hospitals were most prominent, while economic projects consisted mainly of roads, harbors, railways, and other infrastructure development.

The Commission not only has speeded up its procedure for examining and approving investments by the Overseas Development Fund, but it is also ready to help where associated countries find it difficult to finance or undertake global studies on which to base their development needs. One country that the Commission has already helped to overcome this difficulty is Ruanda Urandi, where it is financing a project for a general study of development possibilities.

The most urgent problem connected with overseas countries, however, concerns

'The Italian Government Fund set up to aid development in southern Italy. 
the future of association itself. As these countries become independent, one after the other, they find it unsuitable to be linked to the Community in a form of association in which they themselves have no say, and which, to the new and sensitive nationalism of Africa, may savor of the old colonial days. At the same time, association with the Common Market offers very great advantages, and enlightened African statesmen realize that the Six have much to offer as sources of aid and as markets. It is essential, therefore, to devise as quickly as possible new legal forms through the use of which the overseas countries can be made to feel free and equal partners in an association from which all taint of subordination, however superficial, or even imaginary, has been removed.

\section{H. Labor Policy}

Labor policy has always occupied a somewhat anomalous position in the development of the European Communities. All three Community Treaties leave the bulk of direct responsibility for labor policy firmly in the hands of the national Governments. At the same time, the E.C.S.C. Treaty grants the High Authority very important powers in the field of employment policy, and similar although perhaps less far-reaching powers are vested in the E.E.C. Commission under the E.E.C. Treaty. The problem in the E.C.S.C.-and it is one that is likely to be even more acute in the E.E.C.- has been that of exploiting the Treaty provisions sufficiently to make a powerful enough impact on reemployment, retraining, and resettlement of workers. In the E.C.S.C., the High Authority cannot itself initiate readaptation projects: the proposals have to come from the national Governments. In the E.E.C., readaptation aid is given post facto by the Common Market's Social Fund for projects already undertaken by the existing public authorities. The real testing time for the Social Fund's operations will thus be in the future, and a great deal will probably depend on pressure from the trade unions and on the willingness of the national Governments to make use of the Fund.

In the initial stages of readaptation in the E.C.S.C., the Treaty provisions seemed to be of relatively minor importance. The coal crisis has, however, proved them to be what the French negotiators of the Treaty had envisaged-the major innovation of the Treaty in the social field.

In other fields of labor policy, the function of the Communities has been, and will almost certainly continue to be in the future, to take action and exert their influence in fields where the Treaties grant them only indirect or negligible powers. The E.E.C. has already stated that it intends to make full use of its wide freedom of choice for indirect action, particularly in aiding occupational mobility through training programs. In the E.C.S.C., the High Authority's housing programs, covering roughly 60,000 dwellings, are a typical example of action in a field on which the E.C.S.C. Treaty is silent. Moreover, the wide range of studies undertaken by the Communities-particularly of labor costs and real incomes in the six countries, and also on such subjects as social security, occupational training, industrial health, and 
safety-provide accurate data on which the executives, national Governments, and employers and trade unions can base their policy so as to take account of the whole of the Community's economic area.

\section{The Harmonization of Turnover Taxes}

One of the underlying assumptions of integration through the Communities has been that one cannot remove one or several kinds of trade barriers and leave the others in existence. If one does, the remaining trade barriers can be magnified to supply the protection that has been lost through the abolition of the others. Similarly, the E.C.S.C. has shown that it would have been extremely difficult, in the long run, to integrate parts of the Community's economies and leave other parts unaffected.

This does not mean, as Paul-Henri Spaak pointed out in a memorable debate in the Common Assembly of the E.C.S.C., that one must harmonize everything before one can have a common market. Obviously, the value of a common market is in the real differences between resources and conditions in some parts of the common market and those in other parts-differences in suitability of location, in raw material resources, in geographical features, in aptitudes of the labor force for different operations, and so on. If there were no differences, if some areas did not have advantages over others in particular fields of activity, the advantages of a common market would be far fewer. At the same time, however, it is clear that one cannot leave major distorting factors in the economy.

The E.E.C. Commission has stated unequivocally that the field of fiscal impositions provides one of these major distorting factors. Above all, turnover and sales taxes, imposed at different levels in the member countries, cause artificial differences in production and cost schedules that lead many exporters to feel that despite the removal of trade barriers, they are up against greater difficulties than domestic producers on certain of the Community's national markets. The Commission has recognized the need for a common turnover tax, possibly combined with a sales tax. This is clearly the only ultimate solution, although we may have to be content with partial solutions before the ideal can be achieved. A working party of Commission and Government experts is now examining ways of solving the problem.

\section{J. The Community and the Outside World}

The E.C.S.C. and Euratom, with their limited fields of operation, have had few major problems in the field of external policy. It is true that the levels of export prices for coal and steel were attacked from time to time in the General Agreement on Tariffs and Trade (G.A.T.T.), but the High Authority was able to show fairly conclusively that taking recessions and boom periods together, outside consumers had paid no more than . Community consumers. Euratom was able to conclude cooperation agreements with the United States, Britain, and Canada, and although the technical operation of the United States-Euratom agreement has presented diffi- 
culties, no one could say that either the High Authority or the Euratom Commission has felt itself directly threatened by problems of external policy.

In the case of the Common Market, however, the problems of its relations with the rest of the world, and particularly with its European neighbors, have dominated a large part of its existence. It seems clear that in the long run, the influence of the Common Market must be to produce a general expansion in world trade. Rapid growth within the Common Market will, in turn, bring greater requirements of imports and should be a potent force for rapid economic expansion in the free world. This has been called the creative effect of an economic union on world trade. At the same time, as tariff barriers are removed within the economic union, it is possible-and for some highly sensitive products, probable-that users within the area will switch their purchases from outside suppliers to producers within the area. In this way, they will obtain cheaper products, since, when all internal tariff barriers have been removed, goods produced within the Common Market will not be subject to customs duty.

Another fear of third countries has been that a long-term trend towards selfsufficiency in certain products could appear in the Common Market. The United States has had particular fears on the score of exports of its farm products to the E.E.C. This whole problem depends on whether the undoubtedly expansionary effects of the Common Market are greater, and reveal themselves more rapidly, than the diversionary effects, and also on whether political pressures for selfsufficiency, such as the farmers' lobby, can be kept within reasonable bounds.

All the signs in the Common Market so far point to a generally beneficial effect. In the first place, not only has the Community itself been adopting increasingly liberal policies in the field of its common external tariff and the speedy removal of quota restrictions, but the creation and existence of the Common Market have also generated increasingly liberal and free-trading tendencies in the rest of the world. Rarely have G.A.T.T. negotiations for mutual world-wide tariff reductions been approached in such a liberal spirit as the major free-world countries approached the I960-6I round of negotiations. In addition, the predictions of rapid expansion of production and trade have been fulfilled up to the hilt. Industrial production in the Community in 1959 was about seven per cent greater than in $195^{8}$; and in I960 it was thirteen per cent higher than in r959. Trade within the Community in I959 rose by seventeen per cent over 1958 , and in 1960 by twenty-eight per cent over I959. The Community's trade with other countries in I959 was eight per cent higher than in $195^{8}$, and in 1960 it was sixteen per cent higher than in 1959.

One of the most important problems raised by the Community's external affairs has been its relations with Great Britain. This has been not merely a question of the threat that Britain seems to have seen for its foreign trade, but also a political question. At the time of writing, a general, if as yet ill-defined, British desire to draw closer to Europe may set us on the road to a solution of this fundamental problem, which has, indeed, dogged the course of European integration ever since it began in 1950 . 
Finally, the Community is becoming increasingly aware, as recent pronouncements of the members of the E.E.C. Commission have shown, of the need to help underdeveloped countries. The Community, like other highly developed industrial countries, must aid developing countries by:

a. ensuring that severe price fluctuations for the primary products on which they are largely dependent do not dislocate their development plans;

b. buying their industrial products as their new industries develop, even if their wages are lower; and

c. making a greater effort to provide aid in the form of grants, investment loans, and technical assistance.

These duties are all part of the price that the advanced countries must pay to the rest of the world for being wealthy.

\section{IV}

\section{Some Major Lines of Disagreement}

A. The Supranational Idea: the Letter and the Spirit

The Community system, whether more supranational, as in the case of the E.C.S.C., or less supranational, as in the case of the general Common Market, has features that could not be provided either by traditional national alliances or by intergovernmental cooperation. Through its voting systems-simple majorities in the three executives, and weighted majorities in the Council of Ministers-it prevents the domination of the Community by any of the larger Member States. This is an inestimable advantage for the three small Benelux countries, which are vitally interested in European unity, but not in the resuscitation of the old power blocs.

Moreover, the system has shown its efficacy. It does admittedly demand great understanding on the part of the national Governments, and there have been times when the Governments have wished to brake rather than encourage further development of the Community system. This is hardly to be wondered at when one considers the period of ten years, which is, after all, but a short thread in the loom of history. There are bound to be times when some Governments want to go faster, and times when they want to go slower.

Perhaps the most outstanding and at times unexpected feature of the system's development has been the resilience of the European concept. Time after time, when the drive towards unity seemed to have faltered, it has sought strength in new ideas and new directions and has pushed forward with redoubled momentum.

\section{B. Dirigisme and Laissez-Faire}

The words dirigisme and laissez-faire, representing the two extremes of economic thought, are much in vogue among those who dislike the Community. This is because the Community, like national Governments, has had to steer a sane course between intervention in the economy and total freedom. The decisions made in choosing this course were bound to be the object of major attacks. A great deal of 
misunderstanding has been created on occasion by the unthinking or unscrupulous use of these terms, and it is well to see where the Communities stand in this respect.

In the first place, positive action is clearly needed to get rid of trade barriers and the private forms of restriction and protection. Otherwise, there can be no single market and competition is doomed. It is easy, but quite unjust, to attack such action as dirigisme, when its aim is to produce a truly competitive economy.

Secondly, it has long been clear that industry cannot be allowed complete and unfettered freedom to act as it thinks fit. Laissez-faire, in fact, died long ago, and most liberal economists recognize this. Indeed, what matters is fair competition, and it is the task of governments to safeguard it and to restore it when it has been destroyed. The economy should, therefore, allow a maximum of freedom to initiative and expansion; it cannot, however, allow industrialists the freedom to act in a restrictive way by rationing production or markets, by fixing prices, or by suppressing technical progress.

Thirdly, even if the Community institutions wanted to, they would be unable to follow a dirigiste policy. The Treaties are in themselves liberal documents, and the measures they lay down are almost invariably based on persuasion rather than direct control. The competitive economy has amply proved itself in western Europe in the last ten years, and the Soviet Union itself is now busy introducing competition between firms to increase productivity, having already, in the form of stakhanovitism, introduced cut-throat competition among workers, which is anathema-and rightly so-to our own trade unions.

There is nothing doctrinaire about the Treaties, however. The provisions covering the European Investment Bank, the Social Fund and the Overseas Development Fund, and the conception of agricultural policy show that the Community is prepared to use direct central action and the organization of the market where it considers this necessary.

\section{The Future Development of Integration}

The future development of European economic integration is closely linked with political trends. Will there be a federal system of the type to which the three Community Treaties aspire, or will Europe move towards a confederated system, in which the supreme body will consist of Government representatives? At the time of writing, much hangs in the balance.

For the moment, we must try to advance through concrete measures, as Robert Schuman said in his historic declaration of May 9, I950, for "Europe will not be made in a day." The next stages on which we have set our sights are the merging of the executives of the three Communities and the institution of a system of direct elections, rather than nomination, to the European Parliament.

Whatever the current controversies, one comes back to the experience of the United States, where a confederate system lasted for only a few years. It is hard to avoid the conclusion that confederation can only be a stage on the road to real unity. 